\title{
CRITICA ET BIBLIOGRAPHIA
}

\author{
GyÖNGYÖSI Mária: Стих - цикл - поэтика. Блок, Рильке, Пастернак. Frank- \\ furt am Main: Peter Lang, 2016. 242 S.
}

Mária Gyöngyösi's latest monograph, as the title implies, not only focuses on diverse aspects of the study of Blok's oeuvre but also demonstrates a set of theoretical milestones in the field of comparative literature as well as in prosody (marked by a rich study of the Russian quintet). Having accomplished an exhaustive survey of specific contacts between Blok's poetry and German culture, which details the impact of Novalis, Heinrich Heine, Richard Wagner, and Friedrich Nietzsche on the symbolist poet's unique and complex poetics in her previous monograph (Александр Блок и немецкая культура. Frankfurt am Main: Peter Lang, 2004), the researcher, a full-time lecturer at the Department of Russian Studies at the Eötvös Loránd University in Budapest, continues to explore the presence of German literature in Blok's texts in a broader context of European literature, and identifies links in the poetics of Blok, Rilke, and Pasternak.

A most impressive scholarly work comprised of seven chapters, the book under review fulfils the next step in an ambitious project commeasurable with Zhirmunsky's foresight initiative, who engendered a mainstream in comparative analysis in the same field. By applying a multispectral set of scholarly methods, ranging from the approaches of comparative literature, prosody, semiotics, symbology to philology, contactology as well as the history of reception, Mária Gyöngyösi, a specialist in both Russian and German literature, offers a profound insight into Blok's three volumes of poetry and dramatic texts, chiefly the drama The Rose and the Cross. The final chapter, though dedicated to the study of the manifestations of Blok and Blok's poetics in Yuri Zhivago's Poems concluding the prose part of Pasternak's novel, supplies a discussion of Pasternak's image and an interpretation of the crucial Blokian phenomenon. A Russian reviewer of the same monograph also notes as one of its merits the perfect fluency of the text. A multilevel scrutiny given in each chapter relies on an arsenal of methodological tools, whereas up-to-date results in the field of Blok studies are subject to critical review.

Conclusions concerning the quintessential figure of speech and syncretic philosophical and poetical concept of Radost'-Stradan'ie seem to refer the text of The Rose and the Cross to a multifold complex of links. This will undoubtedly induce a dialogue with Goethe's Faust, which is best classed as intertextual. A fine discussion of this issue placed in Chapter 2 revises the multiple interpretations and commentaries available in respect of Goethe's and Blok's approaches to mysticism, the intention to create a new religion, re-positioning the textual implications of key symbols, amongst them that of the apple tree presented in Blok's drama, the essential semantics of which might be fine-tuned in the light of research done into the subject by E. Slivkin, who addresses the theme of the double omnipresent in Russian literature in a specific way. The intertextual dialogue with Goethe is motivated by a great variety of factors. Advocating the re-reading of the Blokian concept of antagonism between 'culture' and 'civilization', which anticipates the poet's standpoints evolving later on in his Volfila lectures on a theoretical basis, is an outstanding merit of the monograph. 
Further chapters which contain commentaries on Blok's drama elucidate the polysemantic and multifunctional feature of the use of names of Goethe, Ibsen, Schiller, Wagner, and Strindberg termed 'idea-names' by D. Maksimov.

In her introduction to a substantive survey of analogies between Blok's and Rilke's poetry (Chapter 3), Mária Gyöngyösi discusses the reception of Rilke in fin-de-siècle Russia and adequately points out that abundant analogies occurring in the two poets' lyrical product should be written down rather to a commonly shared spirit of the age and the atmosphere of German Symbolism than to any direct influence. Similarly, Blok's scattered references to Rilke committed to paper do not seem to prove much interest in the German poet's art. Apart from a noteworthy visit to Leo Tolstoy, Rilke, who had travelled to Russia several times, had made acquaintance of few Russians by the turn of the century, and met none of the Russian symbolist poets. Consequently, the extensive comparative study aims at unveiling correlations that come under the heading of typological analogies. The magic of the land for Rilke was at the time rooted in an image of Russia clad in Slavophilic ideals. A thorough scrutiny of his urbanistic poems reveals the significance of his early verse Larenopfer, with the authorial invariant of Prague in the focus (the poet deemed them weak, still they were republished in 1913). Yet, these poems facilitate the isolation of distinctive themes, which would dominate an ambience radiating with poverty, darkness, and sadness. Antiurban tunes in Rilke overlapping those in Blok suggest an unequivocal protest against 'the alien' brought about by urbanization. As a most obvious instance, the image of Petersburg, which figures in Blok's lyrical depictions all through his three books of poems, largely stems from the poet's conscious mapping and reconsidering of the myth and concepts, which are conventionally associated with the city. Nonetheless, Blok's own versions, as stressed by Gyöngyösi, reshape the traditional literary landscape, the Petersburgian veduta, primarily following in the footsteps of Pushkin, Gogol, Apollon Grigorjev, Nekrasov, and Dostoevsky. Certain motifs constituting the traditional Petersburg 'Text' can already be detected in Blok's early poetical works (white nights noted earlier by Orlov and hopelessness). They evoke the destiny of the city, sinister prophecies of destruction, and annihilation, underlying expectations of the End times looming. Curiously enough, they bear a close resemblance to Rilke's own picture of Petersburg inspired by impressions of the city that he encountered during a visit. With ample proof presented, the researcher at this point makes a conclusion of cardinal importance. (For that matter, by virtue of disclosing this link Gyöngyösi's deduction in fact makes a worthy contribution to the discipline of geopoetics, which is currently on the rise in Russian literary science.) In the poem Nächtliche Fahrt, besides numerous similarities to Blok's texts, the transformation of real-life experience into poetic texture will be governed by the golden rule of transition 'a realibus ad realiora' (proposed by V. N. Toporov), which typically hallmarks all texts inspired by Petersburg. The same holds for visions of Italy in Rilke's and Blok's poetic imagination, especially in the case of poems prompted by Venice. In these emerges an analogous tendency for depicting borderline situations, binary oppositions of reality vs. dream. Furthermore, via the examination of constructing principles of the lyrical cycles, the researcher provides a long list of analogies and discrepancies.

In a scrupulous scrutiny of the poem Shagi Komandora [The Commendator's Footsteps] in Chapter 6, the researcher's never-ceasing awareness of Blok's philological approach to verbal space yields most productive results: drawing up the family-tree of the sujet of Don Juan going back to centuries, allows her to sight implicit correspondences between the figures of Don Juan and Faust and the profound philosophical potential coded in the sujet. Juxtaposing antecedents beginning with Tirso de Molina, The Stone Guest by 
Pushkin, Don Giovanni by Mozart, each centred upon the theme of penance and repentance, we witness a remarkable change in the prose version offered by E. T. A. Hoffmann. He converts Don Juan into a Romantic hero. For Blok, the element of music penetrating Hoffmann's short story has a high priority. On the other hand, Pushkin's small tragedy, which chiefly relies upon patterns reminiscent of Molière's play, presents the protagonist as the ultimate poet who muses over fulfilment and happiness. Focus shifts to philosophical concepts of the Evil in count A. K. Tolstoy's successive work: this epic poem, a refined amalgam of the elements of the antecedents, elevates love to the status of the heavenly. The remarkable shift in Blok's mythologised version entitled Shagi Komandora is observed in the choice of a lyrical form, moreover, the poet's unorthodox approach lies in depriving the mythical story of its temporal and spatial parameters, whereas the logical pattern of the plot is carefully preserved. According to Gyöngyösi's theory, the substitution of the mythical novel and the integration of the poem into a lyrical cycle suggest Blok's intention to expose a more universal message coded in the sujet.

By tracing Blok's portrait, adaptation of his poetics in Doctor Zhivago, and also underscoring the pivotal statement by Pasternak: 'Blok is Christmas appearing', in the introductory pages of Chapter 7, Gyöngyösi proposes to closely examine a complex network of motifs in the light of 'musical instrumentation'. Comparing the versification of Yuri Zhivago's poems with Blokian orchestration reinforces a close intertextual relationship. In the light of K. Polivanov's assertion which identifies Yuri Zhivago with Blok, the approach is justified. Last but not least, Gyöngyösi argues that the phenomenon of Christmas is linked to the theme of children in Blok's poetics, which extends to memories of the Golden Age. The motifs of the candle, as S. N. Brojtman pointed out, are equally linked to Christmas and Lara, thus, the turning points of the hero's biography allude to the Blokian imagery of Christmas and the Eternal Feminine.

Taken together, Mária Gyöngyösi’s excellent book serves a perfect link to her previous monograph on Blok, complementing the outcome of research. Rich in facts and materials, it showcases numerous results, which are due to rewrite several pages in the history of Russian Symbolism. Benefits for scholars dealing with Blok studies mainly arise from a great number of intriguing conclusions, which are certain to stimulate future research. Theoretical achievements implicate potentials improving methodology. In-depth analysis clearly defines the methods of comparative literature as applicable to hermeneutical investigations.

György Zoltán Józsa

\section{BAKUŁA B. et al. (red.): Dyskurs postkoloniałny we współczesnej literaturze i kulturze Europy środkowo-wschodniej. Polska, Ukraina, Węgry, Słowacja. Poznań: Bonami, 2015. 668 p.}

Initiated by the Polish comparatist Bogusław Bakuła, this voluminous publication is the outcome of an international project focused on the enquiry into post-colonial discourse in Central European culture and literature between 1991 and 2011. The project participants, who were awarded a grant in 2012-2015 included, apart from Poznań Slavonist scholars (Dobrochna Dabert, Emilia Kledzik, Ryszard Kupidura, and Kinga Piotrowiak-Junkiert), also researchers from Hungary (Lajos Pálfalvi), Ukraine (Mykoła Riabczuk), and Slovakia (Renata Deáková and Tibor Žilka). The total of twenty texts written by eight authors (half 
of which were authored by B. Bakuła and R. Kupidura) is introduced by Bakuła's introductory study Europa Środkowo-Wschodnia i jej (post)koloniatny świat, which constitutes a separate thematic unit Postkoloniálni středovýchodni Evropa, whose purpose is to substantiate, adhering to the researches of S. Tötösy de Zepetnek, the pre-1989 concept of Central and Eastern Europe as a post-colonial territory. Hence Bakuła refers to a specific secondary "colonisation" of the Soviet Eastern block through political, economic, and cultural oppression. Central Eastern Europe, defined by Polish scholars as the "interspace" between the Adriatic and the Baltic Seas (consistently opposed to Eurasian Russia), moreover, came under the colonial influence of the West in the form of trashy mass culture, imported mainly from America. Both East- and West-generated impulses, modified to suit the new conditions, were effective even between 1991 and 2011, while the mediating function of cultural values in Central and Eastern Europe assumed a "self-referential" character (S. Tötősy de Zepetnek), becoming the means of national identity and sovereignty.

Divided into thematic units Postkoloniální strategie; Jazyk jako problém postkoloniální středovýchodní Evropy; Film, vynucené fikce, menšiny; Postkoloniální literární př́klady a Otázky identity v postkoloniálni epoše, the other studies describe, from different points of view, the origin, positions, and functions of various societal and artistic phenomena related to post-colonial ideology and poetics within this area. R. Kupidura evaluates the reflection of post-colonial theories in Ukraine, and so does T. Kledzik in Poland; T. Žilka surveys contemporary Slovak postmodern fiction as an aesthetic and value-oriented response to the expressions of post-colonialism. Just as K. Piotrowiak-Junkiert discloses postcolonial elements in Hungarian fiction after 1989. In other papers, D. Dabert gives an analysis of Central and Eastern European cinematography tagged as the wave of "moral unrest"; M. Riabczuk analyses the language policy in Ukraine; and L. Pálfalvi examines the Hungarian creations of non-Hungarian writers. The range of themes also includes construing national identity (R. Deaková) or papers that deconstrue fictions and stereotypes in literary texts (O. Tokarczuk, A. Bodor, V. Pankovčín, M. Kornis, S. Kányádi, etc.).

The importance of this publication lies in the identification and interpretation of postsocialist culture and literature in Central Eastern Europe, on the one hand, and in supplementing Western theories of post-colonialism based on the 'Third World' materials drawn from Asia, Oceania, Africa, and South America, on the other. It shows that the middle position between the Western and Eastern blocks of politically heterogeneous Central Eastern Europe can currently be conceived as a specific area of cultural mediation of "in betweenperipherality", as coined by S. Tötősy de Zepetnek. Rather than a "natural bridge" or simple crossing, Central Eastern Europe thus stands as a "network of interferences and transfers", the site for mutual attraction and repulsion. The distinguishing feature of such a post-colonial model, parallel to imitating more developed cultures, is mainly the endeavour to seek developmental autonomy, which may result in political hegemonism and new nationalisms (e.g. the conflict between Russia and Ukraine, the Balkan wars, etc.). As individual papers on literary prose have revealed, after 1989, these tendencies were reflected in postmodern strategy characterised by the "narrative of change" which was objectified in an apolitical narrative technique, in the accentuation of intertextual irony and mystification, in the frequency of sexual motifs. On the whole, the post-colonial research perspective of this publication will help to enhance understanding of complex political and cultural processes in contemporary Central and Eastern Europe.

Miloš Zelenka 